2, 1966. It would be highly desirable if Great Britain could form a nucleus of a National Gerontological Society with this missing third section for a sociological, psychological and industrial gerontology. Great Britain seems to be one of the few modern States which has not brought about this organizational development. I should like to contact all those interested in the proposals. Research is important, applied research is even more important; but for us now yet more important is an appropriate national organization. My address is: 26 Dransfield Road, Sheffield 10 .

It is hoped to convene a meeting shortly in Birmingham, as a central city, to discuss this more thoroughly and to bring such an organization into being. I should appreciate comments on this article, offers of support and, indeod, offers of funds; a start could be made with a few thousand pounds, and this should yield a considerable return to the nation. This has been a vory brief sketch of the situation, but $I$ appreciate that the whole matter must be discussed by poople from different university disci- plines, from industry and the Trade Unions, and from Government departments, etc.

${ }^{1}$ Report of the Royal Commission on Population (Cmd. 7695, П.M.S.O., London, 1949).

Age and Employment (O.E.C.D., Paris, 1962).

${ }^{3}$ Townsend, P., and Wedderburn, Dorothy, The Aged in the Welfare State (G. Bell and Sons, Ltd., 1965).

Scientific Research in British Universities, 1963-64 (D.S.I.R. and British Council, H.M.S.O., 1964).

Register of Social Research on Old Age, 1960-63 (National Corporation for the Care of Old Pcople).

${ }^{-}$Classified Bibliography of Gerontology and Geriatries, Supp. I, 1945-55; Suppl. II, 1956-61; edit. by Schock, N. (Stanford Univ. Press, 1951).

Handbook of Social Gerontology: Societal Aspects of Ageing, edit. by Tibbitt, E. (Univ. Chicago Press, 1960).

${ }^{8}$ Ageing in Western Societies: A Comparative Survey, edit. by Burgess, E. W. (Univ. Chicago Press, 1960).

${ }^{\circ}$ Handbook of Ageing and the Individual: Psychological and Biological Aspects, edit. by Birren, J. F. (Univ. Chicago l'ress, 1959).

${ }^{10}$ Post, F., The Clinical Psychiatry of Later Life (Pergamon Press, 1965).

" Fleming, C. E., Vita Humana, 694, 177 (1963).

"Fleming, C. E., "The Middle-aged Bulge: A Survey of Age Structure in "leming, C. E., "The Middle-aged Bulge: A Survey of Age Structure in
the lron and Steel Industry", in The Manchester Guardian (now The the lron and Steel Industry', in $T$
Guardian), November 5, p. $9(1957)$.

\title{
OBITUARIES
}

\section{Prof. R. Spärck}

WHEN Ragnar Spärck died on June 20 at the age of sixty-eight his passing left a gap in many circles, created by his central position in Danish zoology, his wide intellectual interests and his extraordinary personality. Few men in his profession have filled so many posts and performed such various duties.

For a period of almost forty years Spärck taught zoology in the University of Coponhagen, from 1937 as professor, occupying the old tradition-rich chair of systematic zoology in the University. The general acknowledgment in Denmark of taxonomy as a necessary background for more recent trends in zoology is largely due to his education of a whole generation of zoologists. Among tho students he was equally popular as an inspiring toacher and a cheerful mid-point during social events and on excursions. His elegant appearance as University opponent at public defences of more than fifty theses was widely appreciated, even by the candidates.

Already as a student, Spärck had acquired a position at the University Zoological Museum. In the early 'twenties he put forward a bold plan for a new museum building; but it was not until he became professor and head of the Museum Council that he could put authority bohind his plans. The Second World War postponed the erection of new and badly needed quarters, but in 1960 the Students' Laboratory and Study Collection was finished and three years later the large staff and rich collections of the Museum moved into an adjacent, wellplanned building. He also played an active part in the consoquent erection of a third, now almost finished, spacious building for comparative anatomy and experimental zoology.

Spärck's contribution to science falls mainly within two fields, marine biology and history. As a pupil of C. G. Johs. Petersen, he carried on his investigations of bottom communities, mainly in areas outside of Denmark. $\mathrm{He}$ wrote his doetoral thesis on the biology of the European oyster and served for the rest of his life as an edviser for the oyster cultivation in the Limfjord. Only to a lesser extent did he join marine expeditions (for example, in tho Mediterranean during the Dana Expedition, in East Greenland, and in South Africa during the Galathea Expedition). However, both before and after the War he was very active behind a long series of Danish expeditions to East Greenland, the Iranean Gulf, West Africa, and not least the Galathea Deep-Sea Expedition. He was vice-president of the Galathea Committee and acted as the co-ordinator on the 'home-front', an extremely important but not widely recognized position during accomplishment of large expeditions.

During his later years Spärck devoted much of his onergy to the history of natural sciences in Denmark. A profound interest in the work and conditions of the predecessors, an extraordinary memory for details and a superior view for general lines was the basis for his important authorship of books and papers on historical subjects, for example, on the Zoological Museum and zoology toaching during 300 years, on early Danish expeditions, on the Natural History Society, and on Japetus Steenstrup, the leading Danish zoologist of the last century, with whom Spärck had so much in common.

Spärck's work for nature conservancy was legendary. He was a member of the Conservancy Council for almost forty years, the last sixteen years serving as a chairman. Ho knew his native country as few others and had an ability to make odds and onds meet in the not always easy negotiations with authorities and proprietors. He was also a leading force behind the Danish game sanctuaries, and, thanks to his initiative, a long series of papers on game biology have been published.

Spärck was well known abroad. He liked travelling and as a result of his broad interests and attainments he attended congresses and meetings within many fields of zoology and marine biology, museum work, nature conservancy and zoological gardens. He was a member of the International Committee of Zoological Congresses and the president of the Copenhagen Congress in 1953. $\mathrm{He}$ was also for six years president of the zoological section of the Intornational Union of Biological Sciences and was a member of several othor international committees (for example, on Zoological Nomenclature, the Zoological Record and Nature Conservancy).

TORBEN WOLFE

\section{Mr. K. E. B. Jay, M.B.E.}

Mr. K. E. B. JAY, who was well known for his popular books on atomic energy, diod at his home in East Hendred, Berkshire, on August 3, at the age of fifty-fivo. Kenneth Edmund Brian Jay was the son of Joseph Jay, a company secretary, of Amersham. From 1923 until 1929 ho was oducated at University Colloge School, London, and then went on to University College, where he read physics. After only a year, his studies were interrupted by a long and painful illness, leaving him with a serious physical disability, which remained for the rest of his life. Jay resumod his studies in 1935 , and in 1938 ho graduated 